Article

\title{
Analyzing Willingness to Pay More to Stay in a Sustainable Hotel
}

\author{
Montserrat Boronat-Navarro ${ }^{1, * \mathbb{B}}$ and José A. Pérez-Aranda ${ }^{2}$ \\ 1 Department of Business Administration and Marketing, Jaume I University, 12071 Castellón, Spain \\ 2 Barcelona School of Tourism, Hospitality and Gastronomy, CETT-Universitat de Barcelona, 08035 Barcelona, \\ Spain; JA.Perez-Aranda@cett.cat \\ * Correspondence: mboronat@uji.es; Tel.: +34-96-472-8541
}

Received: 4 April 2020; Accepted: 28 April 2020; Published: 4 May 2020

check for updates

\begin{abstract}
The aim of this study is to investigate differences in willingness to pay more for sustainable hotels, analyzing whether consumers' searches for information about sustainability, the importance they assign to sustainability certifications, their previous experiences and sociodemographic variables, are all features that influence consumer intentions. We thus contribute to the literature on the importance of consumers' concerns and awareness and how they influence consumer intentions regarding sustainability in the hotel sector. Our results, based on a sample of consumers of various nationalities, show that all the variables analyzed can explain the differences between consumers that are willing to pay more for sustainable hotels and those that are not, except those variables capturing sociodemographic characteristics. These results could help hotel managers to establish strategies to retain more responsible consumers and increase awareness of sustainability, and should prompt them to improve their sustainability practices.
\end{abstract}

Keywords: willingness to pay more; sustainability; hotel sector; previous experiences; searching for information; certifications

\section{Introduction}

The study of the factors that influence consumers' willingness to pay more (WTPM) for sustainable hotels provides crucial information for hotel managers, as well as for society as a whole, which stands to benefit if this sector improves its environmental, social and economic performance. The promotion of responsible management requires the identification of factors that affect the behavior of the different agents in the economy [1], and knowing consumers' intentions should improve the comprehension about their behavior. Thus, the main aim of this paper is to add to the knowledge on the factors that positively influence WTPM. The hotel sector has a major impact on the three pillars of sustainability due to its consumption of natural resources, its effect on the environment, and its economic and social impact on the communities in which such establishments are located [2-4].

The literature on the hotel sector has usually emphasized the environmental aspect of sustainability (e.g., [2,5,6]). Some authors (e.g., [7]) use the terms "sustainable hotel", "green hotel" and "eco-friendly hotel" interchangeably. However, given that sustainability covers aspects other than just environmental issues, in this study, sustainable hotels are considered to be those that employ different practices to address the social and economic as well as the environmental dimensions of the "triple bottom-line" [8]. As indicated by Boronat-Navarro and Pérez-Aranda [9], some examples of sustainable practices include complying with regulations, cutting the consumption of natural resources, introducing policies to improve work-life balance, or establishing funding programs that support disadvantaged groups (see [9] for a more exhaustive list of corporate social actions). 
Consumers' positive attitudes and intentions towards sustainability could prompt hotels to adopt new sustainable practices and improve existing ones [3]. Making hotels more sustainable requires small actions as well as major investments to adapt processes and infrastructure, which in turn could cause hoteliers to raise their prices [2]. Indeed, one of the main concerns for consumers when deciding whether to stay in more sustainable hotels is the higher price [10].

Scholars in the hospitality literature report conflicting findings about WTPM for sustainable establishments [11-13]. Improving the knowledge on responsible consumers could be a critical contribution to this literature.

Specifically, following the line of research that analyzes the relevance of customers' awareness of and concerns about sustainability $[2,6,14]$, the aim of this research is to examine how consumers' searches for information about sustainability, the importance they assign to sustainability certifications, and their previous experience, as well as certain sociodemographic factors, influence consumers' willingness to pay higher prices for sustainable hotels. This research therefore attempts to answer the following research questions: (1) Do consumers who are more aware about a hotel's Corporate Social Responsibility (CSR) due to their searches about hotel practices show higher WTPM to stay in a sustainable hotel? (2) Do consumers that attribute importance to a hotel's sustainability certifications show higher WTPM to stay in a sustainable hotel? (3) Do previous experiences with sustainable hotels affect consumer's WTPM to stay in a sustainable hotel? (4) How does consumers' WTPM differ across sociodemographic variables? This analysis is relevant for hotel managers [6], since the results can help them to establish strategies to differentiate their services, to retain more responsible customers and to raise awareness about the vital need for sustainability. In turn, the findings of this study could reveal an opportunity for the hotel sector to mitigate its negative impacts on the environment and society, and bolster its positive impacts. This is especially important in a country such as Spain, which is the second most visited country in the world $[3,15]$ and where the tourism sector accounts for $12 \%$ of GDP [16]. The analysis of consumers' WTPM for sustainable establishments may motivate hotels to improve their sustainability [3].

The following section presents the literature review on which to base the hypotheses. To that end, we first present the studies about willingness to pay (WTP) in the hotel sector, then explain our choice of variables that influence consumer intentions, and finally propose our hypotheses. Then, in the methodology section, we present the sample, the measurement and method used, before detailing our results in the following section. We then discuss the results and finish with the conclusions.

\section{Literature Review}

\subsection{Theoretical Background and WTPM}

The present study lies within the framework of the theory of planned behavior $[17,18]$ as it focuses on consumers' intentions and their predictors, and this theory provides a framework to analyze the antecedents of consumers' behavior. Within this framework, intentions can be seen as antecedents of behavior, while predictors of intentions include attitudes, subjective norms and behavioral control. The framework has been applied to the study of CSR and sustainability in the hospitality sector to explain the antecedents of consumers' sustainable behaviors (e.g., [2,3,19]).

WTP refers to the maximum monetary value that consumers assign to, and are willing to spend on, a product or service [20-24]. It indicates favorable future behavior towards the product or service [20], since it reflects consumer intentions and their conscious predisposition [25] towards paying a certain amount in the future. WTPM has been studied in the literature as a key indicator of intentions [26], and intentions are central to the theory of planned behavior [18], wherein intentions are understood as antecedents of behavior in the process of individual decision-making [27].

The literature has reported differing results regarding WTP for sustainable hotels, or specifically for green hotels, since these studies focus mainly on environmental-friendly practices in hotels (e.g., $[2,5,6,13,28])$. For example, Lee et al. [13] show that U.S. hotel guests who have previously stayed 
in a green hotel are less motivated to pay a premium for a hotel's environmental sustainability. In the study by Manaktola and Jauhari [28], Indian consumers are not willing to pay a premium for green practices in hotels, while in the Millar and Baloglu [29] study, only $18 \%$ of the sample show higher WTP for these practices. In the case of Kang et al. [2], they report positive WTP values but show that U.S. customers staying at higher-rated hotels are more willing to pay for green practices than those staying at more economical hotels. Fuentes-Moraleda et al. [3], in a study about how sociodemographic variables and commitment affect WTP, find that more than the half of the consumers in their sample (52.4\%) are willing to pay a premium for hotels applying green practices. Tang and Lam [30], using a sample of Generation-Y Chinese customers, find that positive WTP depends on different personal traits.

Therefore, in light of these conflicting findings, we perform an in-depth analysis of the factors that could differentiate between consumers who are more and less willing to pay a premium for hotels. We define sustainable hotels as those that implement practices relating to economic, social and environmental aspects of sustainability. Other authors employ a similar definition of sustainable hotels, such as Barber and Deale [31] in their study of sustainable behavior in U.S. hotel guests.

\subsection{Analyzing Consumers' WTPM for Sustainable Hotels}

In the theory of planned behavior, behavioral intentions, such as WTP, are viewed as antecedents of behavior $[17,18]$, whereas attitudes are one of the crucial factors explaining the formation of these intentions $[17,32]$. The other two determining factors proposed in the theory-namely subjective norms or social pressure, and perceived behavioral control or the consumer's perception of obstacles [14] have been shown to have no effect in some contexts, such as fair-trade purchasing decisions [33]. Further developments based on this theory have incorporated other factors explaining consumer intentions [9,14,34] that can increase the predictive power of the model $[18,19,35]$. For example, studies applying this theory to the hotel sector have analyzed concerns, attitudes, commitment, or awareness (e.g., [2,3,6]). Regarding the environmental side of sustainability, concerns are attitudes about facts or behaviors that affect the environment $[26,36]$, a concept that could be applied to concerns about sustainability.

Taking into account the fact that price is one of the main barriers to green consumption [10,37], it is worth studying whether more aware consumers show higher WTPM. This would enable us to add to the knowledge obtained from other studies (e.g., [2,3,6]) and to offer hotel managers more information about which factors influence consumers' intentions about sustainability. Specifically, information and awareness have been proposed as one of the factors that can improve the consumer's sustainable intentions and behaviors [14]. Third-party certifications, such as environmental certifications, are a means of providing accurate information to consumers and other stakeholders about hotels' application of sustainable practices [38]. In fact, such information has been analyzed as a factor that modifies the relationships between the variables proposed in the theory of planned behavior [39]. Furthermore, the importance of previous experiences in the formation of intentions is also highlighted in the theory of planned behavior [6,40-42]. Therefore, in this study, we analyze consumers' search for information about sustainability, the importance of hotels' certification, and consumers' previous experiences as factors determining sustainable intentions. The analysis also incorporates consumers' sociodemographic characteristics, since they could influence individuals' cognitive processes or resources, which in turn can affect intentions [3,6].

\subsubsection{Consumers' Search for Information about Hotels' Sustainability}

Concern about sustainability is an attitude regarding one's own and others' behavior in terms of the consequences it has for sustainability [26,36]. Studies about consumers' concern about sustainability, which mainly focus on the environmental aspect of sustainability, show that more concerned consumers are willing to pay more for environmentally-friendly products or services (e.g., [43-45]).

Consumers that are conscious of the importance of sustainability are more likely to take this variable into account as a factor in their purchase decisions, as they attempt to make sustainable 
choices [6]. For effective decision-making, consumers need information about the firm; in this case, about hotel practices. In this regard, Manaktola and Jauhari [28] show that customers' awareness of sustainable hotel practices influences their preference for this type of establishment. This awareness has also been analyzed in the marketing literature as a requisite for consumers' positive reactions [46,47]. Consumer searches for information about hotel CSR could even modify the relationship between the importance of the different dimensions of CSR and consumers' support for sustainability [9]. Information processing theory [48] explains the relevant role of information as key to understanding human behavior and decision-making. According to this theory, consumers' awareness of hotel practices regarding sustainability is crucial for decision-making based on sustainable practices [45].

Information has been also studied in the context of the theory of planned behavior; for example, Pérez and García de los Salmones [14] propose a model, also incorporating other theories, in which the gap between intentions and behavior can be explained by information asymmetries. Behavioral intentions such as WTPM for sustainable establishments could be influenced by consumers' awareness of the hotel's practices. Pomering and Dolnicar [47] and Sen et al. [49] show how firms' implementation of CSR practices helps generate more positive consumer attitudes and intentions. However, for CSR to have an influence on their decisions, consumers must be aware of these practices [45]. Therefore, we propose that consumers that search for a hotel's CSR practices are more willing to pay for sustainable practices. Thus, the following hypothesis is proposed:

H1. WTPM for a sustainable hotel is higher among consumers who search for information about the hotel's CSR practices.

\subsubsection{Importance of Hotel Certifications for Consumers}

Certifications are standardized schemes aimed at fostering the adoption of sustainability practices and are a way of promoting a voluntary approach to include, measure and report good practices regarding the environmental, social and economic pillars of sustainability. They indicate a firm's voluntary commitment to sustainable principles. These management systems enhance firms' ability to achieve sustainability [50] by establishing predefined processes and objectives that firms need to accomplish in order to obtain the certification [51]. They could even be considered as an indicator of the sustainability achieved [38].

Most of these certification schemes are focused specifically on pro-environmental actions while others include a wider range of aspects related to the different dimensions of sustainability (e.g., ISO 26000). Regarding the tourism industry, Geerts [52] and Martínez-Perales et al. [38] enumerate the different benefits of environmental certifications, such us eliminating practices that produce negative environmental effects, cost savings, appealing to more environmentally conscious consumers, and even acting as a means of providing accurate information to consumers about hotels' environmental performance. Martínez-Perales et al. [38] analyze the correspondence between certifications and the three pillars of sustainability. Even the ISO 14001 scheme, which promotes environmental management systems, aims to achieve a balance between the environmental, social and economic dimensions, and is therefore aligned with the idea behind sustainability [38].

Certification is a way of offering more information, transparency and credibility about firm practices; therefore, it simplifies the search for information [14]. It implies third-party auditing and therefore enables consumers and other stakeholders to gain verified information about hotels' application of sustainable practices [38], providing a guarantee of firms' quality and reliability [26,53].

More conscious consumers that search for hotels' sustainability information would thus consider it relevant whether or not hotels hold these certifications. Following studies that suggest certifications are a way for hotel establishments to appeal to more conscious customers [26,54], we propose that consumers who attribute importance to the hotel's certification are also more likely to have positive intentions regarding this establishment; specifically, they could be more willing to pay a higher price for sustainable hotels. Hence, we propose the following hypothesis: 
H2. WTPM for a sustainable hotel is higher among consumers who attribute importance to hotel certifications.

\subsubsection{Previous Experience with Sustainable Hotels}

More recent developments in the theory of planned behavior suggest that previous experience may influence intentions [40-42]. Authors testing the validity of the theory of planned behavior have found that past experiences predict intentions and behavior (e.g., [55-58]). Previous experiences play a fundamental role for hotel customers [6].

A number of different studies have proposed the influence of previous experiences on intentions [40-42], and they may be an even stronger determinant in the case of services. For example, Buhalis [59], in an analysis of travelers and destinations, found that, among other variables, past experiences are associated with behavior. Additionally, behavioral intentions have been shown to be influenced by previous experience in the case of intangible products or services $[20,40,60]$. The intangible nature of services means that it is harder for customers to predict the service if they do not have previous experience of it [61].

When the customer has previous experience with sustainable hotels, they are more aware of the kind of sustainable practices and services hotels can include and have more knowledge about the associated benefits; as a consequence, this positively affects their intentions towards these hotels. On the contrary, non-experienced consumers may not know, for example, which different services, and even actions, sustainable hotels offer $[6,20]$. Therefore, experienced consumers may be more willing to pay a higher price for sustainable hotels [6]. Hence, we propose the third hypothesis:

H3. Consumers that have previous experience with sustainable hotels are willing to pay more for a sustainable hotel.

\subsubsection{Consumers' Demographic Characteristics}

According to the literature, the sociodemographic variables typically used to analyze customers' decision-making in the hospitality sector should also be included in the analysis of sustainable attitudes and intentions $[3,6]$.

The arguments proposed in the literature to explain the influence of demographic variables such as gender are based on the differences between men and women in how they process information [62,63], or in the importance they give to values [64], or even, according to the social theory [65], because they behave in an different way in society [66]. Nevertheless, the findings are inconsistent, with some studies showing women are more willing to pay more for green initiatives (e.g., [64]), others showing men are (e.g., [2]), while others report a non-significant relationship (e.g., [67]).

Furthermore, customers' cognitive processes may change over their lifetime [68]; therefore, age has also been proposed as an important variable that affects CSR concerns [69]. Some studies have also found that the information processing abilities differ depending on age, and could imply that younger people have more access to different information about sustainability issues [6,20]. Nevertheless, Turley and Cabaniss [70], did not find gender and age to have a significant influence on price awareness. Similarly, Kuchinka et al. [71] found no differences in attitudes towards sustainability in consumers depending on age or gender, while Namkung and Jang [20] only found differences in the case of age.

Han et al. [6], among others, also claim that education and income play a relevant role in the formation of eco-friendly intentions, arguing that higher levels of both facilitate responsible behavior, although they do not find a significant effect. Fuentes-Moraleda et al. [3] confirmed the positive influence of higher incomes on intentions, but did not find a positive relationship in the case of education. Some others even found a negative relationship (e.g., [2]) offering the explanation that low-income customers are more affected by environmental problems and therefore show more sensitivity to these issues.

Cultural differences among countries or cultural distance is another variable that has been included in tourist studies analyzing attitudes and intentions regarding sustainability. Although the use of nationality as a proxy for culture is not free from criticism (e.g., [72]), several studies 
have revealed differences between tourists from different countries. Kang and Moscardo [73] found differences in attitudes regarding responsible behavior. Cordano et al. [74], Hudson and Ritchie [75], and Maignan [76] also found differences in pro-environmental or sustainable attitudes and behavior across countries. Nevertheless, Kuchinka et al. [71] or Takayama et al. [77] are examples of studies that did not find these differences across countries.

Therefore, the studies that have analyzed the effect of sociodemographic characteristics on consumer intentions and behaviors regarding sustainability and CSR show dissimilar results; as such, the influence of these variables needs to be further tested. Thus, we include them in our analysis by proposing the following series of hypotheses:

H4. WTPM for sustainable hotels differs according to the consumer's sociodemographic traits.

H4a. WTPM for sustainable hotels differs according to the consumer's gender.

H4b. WTPM for sustainable hotels differs according to the consumer's age.

H4c. WTPM for sustainable hotels differs according to the consumer's monthly income.

H4d. WTPM for sustainable hotels differs according to the consumer's nationality.

\section{Methodology}

\subsection{Data}

We collected a convenience sample, gathering data from foreign tourists in Barcelona, a large iconic Spanish city. We chose Barcelona in order to obtain a sample that includes tourists from different countries to test our hypotheses, since it is the most visited city in Spain and the fifth most visited in Europe. In addition, it ranked 25th in the "Top 100 city destinations ranking" published in 2015 by Euromonitor International, based on data from arrivals in 2013 [78]. Given the difficulties in accessing the complete sampling frame, as 7,874,941 foreign tourists stayed at least one night in a Barcelona hotel in 2014, according to official figures [79], a convenience sampling technique was considered suitable (e.g., [80,81]). Following the procedures of other studies in this area (e.g., [19,82-85]), trained interviewers randomly intercepted tourists in Barcelona outside four of the main tourist spots; according to official data [86], these include the Sagrada Família Basilica, Park Güell, Poble Espanyol de Montjüic, and El Born. Tourists were first asked whether they had stayed at least one night in any hotel in the city. Those who answered affirmatively were informed about the purpose of the study and asked if they would be willing to participate by answering the interviewers' questions. They were also told that their responses would remain anonymous in an aggregate treatment of the data [87].

The questionnaire was prepared in Spanish and translated into four languages: English, French, Italian and German. Each survey lasted an average of $15 \mathrm{~min}$ (it includes more questions since it is part of a wider research project, including, for example, questions aimed at assessing consumers' perception about different dimensions of CSR; for details see [88]). In terms of the structure of the questionnaire, after the presentation of the study, the first part asks about WTPM, which allows us to measure our dependent variable. This was included in the first part to reduce potential problems due to priming effects [87], since the second part of the questionnaire includes other questions about CSR dimensions. The following section contains questions aimed at capturing data about information searches, previous experiences and hotel certification, while the questions about sociodemographic variables are included in the final section.

The fieldwork was carried out between June and September 2015, a year which could be considered as falling within the post-economic crisis period. As such, it could help provide an understanding of consumers' intentions regarding sustainable behavior following such episodes, where the tourism industry is particularly adversely affected. Understanding which factors affected consumer intentions in the past could help open up new lines of research to further investigate these relationships and to raise awareness about sustainability issues. 
Compared to other methods, face-to-face surveys have featured more prominently in consumer studies in the past (e.g., [89]), although they are more expensive to carry out. We therefore predefined an acceptable sample size of between 700 and 800 surveys, taking into account cost efficiency and time effectiveness issues [90]. We obtained 760 surveys and after removing 11 invalid answers, we ended up with 749 usable responses. Moreover, the sample size is considered large enough as it is well above the minimum threshold of 10 cases for each independent variable, in line with multiple regression guidelines [91]. Our ratio of valid cases to the number of independent variables (749/8) is 93.6, far above the 10 cases required. Our sample also exceeds the number required for ANOVA tests for the medium and large effect size [92].

Regarding the demographic characteristics of the sample, $47.53 \%$ are female and $52.47 \%$ male; $55.5 \%$ of the sample are aged between 18 and 29 years old, $21.8 \%$ between 30 and 39 years old, and $22.7 \%$ are 40 or over; $17.2 \%$ of the sample have completed high school or a lower level of education, $26.2 \%$ have a vocational qualification, $40.9 \%$ are college graduates, and $15.1 \%$ have completed a master's or a doctoral degree; regarding their net monthly income, $20.5 \%$ of the sample have no income at all, $27.0 \%$ have an income under 1500 euros, 28.4\% have between 1501 and 2500 euros, $14.4 \%$ between 2501 and 3500 euros, and $9.7 \%$ earn over 3500 euros a month; $25.0 \%$ of the sample are French tourists, $25.6 \%$ are British, $19.6 \%$ are Italian, $21.8 \%$ are German, and $8.0 \%$ are a variety of different nationalities including Portuguese, Russian, Chinese and American.

\subsection{Measurement of Variables}

\subsubsection{Willingness to Pay More for a Sustainable Hotel}

This variable is measured with the following item: "I am willing to pay more for a responsible hotel". It ranges from 1 (totally disagree) to 5 (totally agree). Other studies that also analyze WTPM for green or sustainable hotels measure this variable in a similar way (e.g., [2,3]). A sustainable hotel is defined in the survey as those that implement practices relating to the economic, social and environmental aspects of sustainability.

\subsubsection{Search for CSR Information}

Following similar approaches in the literature (e.g., $[93,94])$, we measure this variable with an item that asks about tourists' search for information about hotels' CSR practices. Scores range from 1 to 5, with the lowest indicating that they never search for information about hotels' CSR practices, and the highest meaning that they always search for information about a hotel's CSR practices when they search for hotel information or characteristics.

\subsubsection{Importance for Consumers of Hotel's Sustainability Certification}

This variable is coded as dichotomous, with 0 indicating that the tourist does not attribute any importance to the hotel's sustainability certification and 1 indicating that they do attribute importance to these certifications. When asking these questions, interviewers mention different examples of certifications, such as IQNet SR10, ISO 26000, ISO 14001, EMAS, EFQM or OSHAS 18001.

\subsubsection{Consumer's Previous Experience with a Sustainable Hotel}

In this case, following the study of Han et al. [6], this is a dichotomous variable where 0 indicates that the tourist had not previously paid to stay in a sustainable hotel and 1 indicates that they had already stayed in a sustainable hotel.

\subsubsection{Demographic Variables}

Gender is a dichotomous variable (male/female).

Age is divided into the following ranges: 18-29 years old, 30-39 years old, and 40 or over. 
The variable Educational level includes the following categories: completed high-school level or below, vocational qualification, college graduate, and master's or doctoral degree.

The Level of monthly income is categorized in the following groups: no income, under 1500 euros, between 1501 and 2500 euros, between 2501 and 3500 euros, and over 3500 euros.

Respondents were asked also about their nationality. Given the fact that the vast majority of respondents are from France, the United Kingdom, Italy and Germany, we codify the variable Nationality into the following categories: French, British, Italian, German, and Others. The category Others ( $8.0 \%$ of the total sample) includes Portuguese, Russian, Chinese and American.

\subsection{Methods}

We analyze differences in WTPM for sustainable hotels for each proposed variable. Following the procedures outlined in other studies on this topic (e.g., [2]), in order to investigate how consumers' WTPM differs based on their searches for CSR information, the importance they assign to sustainability certifications, their previous experience with a sustainable hotel, and their sociodemographic variables, we first perform a univariate analysis of WTPM, analyzing mean differences in WTPM for each variable. In the case of the dichotomous variables, Previous experience with a sustainable hotel, Importance of hotel's sustainability certifications, and Gender, we perform an independent $t$-test that allows the comparison in means in two groups, to analyze group differences in WTPM for each of these dichotomous variables. For the rest of the variables, which include more than two categories or values, requiring thus the comparison in means of more than two groups, we employ the analysis of variance (ANOVA). This analysis is performed to investigate whether or not WTPM differs across each one of these multiple categorical variables.

We then retain the significant variables from this analysis and carry out a multiple regression analysis to confirm the results.

\section{Results}

Table 1 shows the results regarding the main variables. All of them show statistically significant differences in WTPM for a more sustainable hotel (see Table 1 where t-values are shown for comparison in dichotomous variables and the F-value for the variable, Search for hotel's CSR information). Experienced tourists register higher mean values for WTPM than non-experienced tourists $\left(M_{\text {experienced }}\right.$ $=3.142$ vs. $M_{\text {non-experienced }}=2.828$ ). Likewise, consumers that attribute importance to the fact that the hotel has some kind of certification for their sustainability practices are more willing to pay a premium for a sustainable hotel than those customers that do not attribute any importance to the hotel's certification $\left(M_{\text {certification importance }}=3.357\right.$ vs. $\left.M_{\text {certification not important }}=2.934\right)$. In the same regard, more informed consumers are more willing to pay more, and the mean value of the variable rises as the variable represents more informed consumers. Specifically, the highest mean value is shown for the consumers that always search for the hotel's CSR information when they are looking for a hotel $\left(M_{\text {always }}=3.745\right)$, followed by those that often search for CSR information $\left(M_{\text {often }}=3.584\right)$, and sometimes $\left(M_{\text {sometimes }}=3.196\right)$, with low values in the case of consumers that almost never search for this information $\left(M_{\text {almost }}\right.$ never $\left.=2.713\right)$, and those that never search registering the lowest value $\left(M_{\text {never }}=2.361\right)$.

As in the previous table, Table 2 shows the results for the comparison of means with the $t$-value or the F-value (depending on the type of the variable analyzed); in this case, indicating the differences in WTPM for a sustainable hotel for the sociodemographic variables. Only the Gender variable shows significant differences $(F=2.526 ; p=0.012)$. Women show higher mean values for WTPM for a responsible hotel than men $\left(M_{\text {female }}=3.122\right.$ vs. $\left.M_{\text {male }}=2.898\right)$. The youngest sector of the sample shows the highest mean score $\left(M_{\text {between }} 18\right.$ and 29 year $\left.=3.000\right)$ but there are no significant differences according to the ANOVA test $(F=0.201 ; p=0.818)$. In the case of Education, college graduates show the highest mean score $\left(M_{\text {college graduates }}=3.085\right)$, but again, the differences are not significant $(F=$ 0.925; $p=0.428)$. Likewise, no significant differences are found in the analysis of monthly income $(F=$ 
1.494; $p=0.203$ ) or nationality ( $F=1.045 ; p=0.383$ ). Therefore, except for gender, the sociodemographic characteristics do not appear to be determinants of consumers' WTPM for a more sustainable hotel.

Table 1. Results of $t$-Test and ANOVA for the effect of different variables on willingness to pay more (WTPM).

\begin{tabular}{cccccc}
\hline Variable & Variable Coding & Mean & Std. Deviation & $t$-Value & $p$-Value \\
\hline $\begin{array}{c}\text { Previous experience } \\
\text { with a sustainable hotel }\end{array}$ & Yes & 3.142 & 1.202 & $3.595^{* * *}$ & 0.000 \\
$\begin{array}{c}\text { Importance of hotel's } \\
\begin{array}{c}\text { sustainability } \\
\text { certifications }\end{array}\end{array}$ & No & 2.828 & 1.186 & & \\
& No & 3.357 & 1.272 & $2.966^{* * *}$ & 0.003 \\
\hline Variable & Variable Coding & Mean & Std. Deviation & F-Value & $p$-Value \\
\hline Search for hotel's CSR & Always & 3.745 & 1.406 & $24.368^{* * *}$ & 0.000 \\
information & Often & 3.584 & 1.085 & & \\
& Sometimes & 3.196 & 1.093 & & \\
& Almost never & 2.713 & 1.125 & & \\
& Never & 2.361 & 1.047 & & \\
\hline
\end{tabular}

$\left(^{*}\right) p$-value $<0.10 ;\left({ }^{* *}\right) p$-value $<0.05 ;(* *) p$-value $<0.01$.

Table 2. Results of $t$-Test and ANOVA for the effect of demographic variables on WTPM.

\begin{tabular}{|c|c|c|c|c|c|}
\hline Variable & Variable Coding & Mean & Std. Deviation & $t$-Value & $p$-Value \\
\hline \multirow[t]{2}{*}{ Gender } & Female & 3.122 & 1.186 & 2.526 & $0.012 * *$ \\
\hline & Male & 2.898 & 1.204 & & \\
\hline Variable & Variable Coding & Mean & Std. Deviation & $F$-Value & $p$-Value \\
\hline \multirow[t]{3}{*}{ Age } & $18-29$ years & 3.000 & 1.387 & 0.201 & 0.818 \\
\hline & 30-39 years & 2.792 & 1.250 & & \\
\hline & 40 or over & 2.960 & 1.428 & & \\
\hline \multirow[t]{4}{*}{ Education } & $\begin{array}{l}\text { High school or } \\
\text { lower }\end{array}$ & 2.977 & 1.221 & 0.925 & 0.428 \\
\hline & $\begin{array}{l}\text { Vocational } \\
\text { qualification }\end{array}$ & 2.984 & 1.224 & & \\
\hline & College graduate & 3.085 & 1.178 & & \\
\hline & $\begin{array}{l}\text { Master's or } \\
\text { doctoral degree }\end{array}$ & 2.870 & 1.208 & & \\
\hline \multirow[t]{5}{*}{ Monthly income } & No income & 2.822 & 1.144 & 1.494 & 0.203 \\
\hline & Under 1500 euros & 3.098 & 1.211 & & \\
\hline & $1501-2500$ euros & 3.157 & 1.171 & & \\
\hline & 2501-3500 euros & 2.986 & 1.165 & & \\
\hline & Over 3500 euros & 3.188 & 1.249 & & \\
\hline \multirow[t]{5}{*}{ Nationality } & French & 2.989 & 1.187 & 1.045 & 0.383 \\
\hline & British & 2.899 & 1.248 & & \\
\hline & Italian & 3.140 & 1.072 & & \\
\hline & German & 3.056 & 1.209 & & \\
\hline & Other & 2.881 & 1.403 & & \\
\hline
\end{tabular}

$\left(^{*}\right) p$-value $<0.10 ;\left({ }^{* *}\right) p$-value $<0.05 ;(* *) p$-value $<0.01$.

We then perform a multiple regression analysis retaining only the significant variables (i.e., Search for hotel's CSR information, Importance of hotel's certifications, Previous experience with sustainable hotels, and Gender). Results are shown in Table 3. 
Table 3. Results of the regression on WTPM.

\begin{tabular}{cccc}
\hline Variable & Standardized Coefficient & $\boldsymbol{t}$-Value & $p$-Value \\
\hline $\begin{array}{c}\text { Search for hotel's CSR information } \\
\text { Importance of hotel's }\end{array}$ & 0.268 & $5.147^{* * *}$ & 0.000 \\
sustainability certifications & 0.123 & $2.443^{* * *}$ & 0.015 \\
Previous experience with a & & & \\
sustainable hotel & 0.087 & $1.751^{*}$ & 0.081 \\
Gender & 0.061 & 1.284 & 0.200 \\
F-value & & $15.156^{* * *}$ & \\
Adjusted R-square & & 0.127 & \\
\hline
\end{tabular}

$\left.{ }^{*}\right) p$-value $\left.<0.10 ;{ }^{* *}\right) p$-value $<0.05 ;\left(^{(* *)} p\right.$-value $<0.01$.

The model fits well with an F-value of 15.156 ( $p$-value $<0.000)$, and an adjusted r-square of 0.127 (similar to values reported in other studies on the topic, such as Kang et al. [2]). Results in Table 3 confirm the previous results except in the case of the demographic variable Gender, which is non-significant. Therefore, the factors explaining WTP are the Search for hotel's CSR information $(\beta=0.268 ; p$-value $<0.01)$, Importance given to hotel's sustainability certifications $(\beta=0.123 ; p$-value $<0.01)$, and Previous experience with a sustainable hotel $(\beta=0.087 ; p$-value $<0.10)$. Therefore, the analyses performed allow us to confirm Hypotheses 1,2 and 3. Nevertheless, we cannot confirm the series of hypotheses regarding the demographic variables (Hypothesis 4). In the t-test analysis (Table 2), Gender was significant, but in the regression analysis (Table 3), it is non-significant.

\section{Discussion}

The results of this study confirm the findings of previous literature analyzing the effect of consumers' awareness on their behavioral intentions regarding sustainability (e.g., [28,43-45]). Specifically, we confirm differences in WTPM for a sustainable hotel between more and less informed consumers, between more and less experienced consumers in terms of previous stays in sustainable hotels, and between consumers that view sustainability certifications as important and those that do not.

Our study finds that consumers who are more aware of and concerned about sustainability, and who specifically make the effort to search for information about the hotel's CSR practices, register higher values for WTPM for sustainable hotels. Similarly, consumers who value a hotel's sustainability certifications are willing to pay more for a sustainable hotel, which corroborates the previous result about more informed consumers, since certification is also a way of providing more reliable information to stakeholders, including consumers. These results confirm and extend previous studies that point to the important role played by consumer awareness and information in intentions about sustainability (e.g., [14]). Manaktola and Jauhari [28] claim that when customers are aware of a sustainable hotel's practices they prefer to stay in such hotels, and our results show that consumers are even willing to pay more for these hotels. This is in line with findings about the need for awareness of CSR practices in order for consumers to have positive reactions to them $([46,47])$. These results also confirm previous findings about the importance of certifications in attracting more responsible consumers [38,54].

Furthermore, more concerned consumers that have already stayed in a sustainable hotel-meaning they know about and have specifically searched for this type of hotel—are also more willing to pay higher prices for these establishments. This is in line with the literature that analyzes the importance of previous experiences on intentions [6,40-42]. Specifically, our study corroborates the results reported by Han et al. [6], who tested this effect in a sample of 422 U.S. hotel customers.

All these variables are shown to play a more relevant role than the sociodemographic variables in differences in consumers' WTPM for a sustainable hotel. Indeed, the only relevant sociodemographic variable is gender, albeit only partially because the regression analysis has not confirmed this result. This is in line with the results obtained in the study by Han et al. [6], in which gender was the only significant demographic variable, while age, income, and education did not show a relevant effect on 
WTP. Our results point in the same direction as those reported by Han et al. [6], since women register higher mean values for WTPM for sustainable hotels.

Although there is a lack of consensus in the empirical studies about the effect of demographic variables on intentions (e.g., [2,20,71]), our analysis specifically corroborates the results reported by Kang et al. [2] and Han et al. [6], showing that gender is the only demographic variable that has an effect on WTPM for a sustainable hotel. The two aforementioned studies analyze WTP, both with a sample of customers in U.S. hotels. Our study is set in a European context but reaches the same conclusions regarding these sociodemographic variables. However, the direction of the relationship with gender is different in the study of Kang et al. [2], in which male customers show higher values for WTPM. These conflicting results indicate that Gender is a variable that needs further study in the analysis of WTPM for sustainable hotels. The more recent study by Fuentes-Moraleda et al. [3] finds differences regarding Income and Age in WTPM, but no differences regarding Gender and Education. Nevertheless, the context of study in the latter was customers of boutique hotels with an environmental management system, which could imply a particular segment of customers with a specific profile. It is interesting that our results show no differences between nationalities regarding intentions about sustainability. The fact that most of the tourists in our sample come from European countries could be an explanation for these results, since the cultural distance may not be so great as to have different effects on intentions regarding sustainability. Kim et al. [95] found differences between U.S. and Korean consumers of fair-trade products, arguing that these results were due in part to the different level of knowledge about these products in the two countries. In our sample, it seems that these differences are not so great between different countries, but rather within countries between more and less informed customers.

Overall, these results imply that variables other than the demographic ones play a more relevant role in the analysis of WTPM for sustainability in the hotel sector. Specifically, the differences between more and less informed consumers, between those that attribute importance to hotel certifications and those that do not, and between customers who have experience with sustainable hotels and those that do not, are relevant variables in the analysis of consumers and their WTPM for a sustainable hotel.

\section{Conclusions}

This study extends the line of research that analyzes the importance of consumer concerns and awareness in order to enhance consumers' positive intentions regarding sustainability in the hotel sector. Adding to the knowledge about the factors that have a positive influence on the WTPM for a sustainable hotel, this paper provides empirical support for the importance of searching for CSR information, consumer perceptions of hotels' certification, and previous experience with sustainable hotels as relevant factors characterizing consumers with positive intentions in terms of WTPM. In light of the results obtained, we can answer the research questions set out in the introduction, concluding that consumers that search for information about hotel CSR practices, and who are thus more aware about hotels' sustainability, show higher WTPM to stay in a sustainable hotel. Likewise, consumers that attribute importance to a hotel's sustainability certifications also register higher WTPM for more responsible hotels. In addition, consumers' previous experiences with sustainable hotels are also a factor that positively influence their WTPM for a sustainable hotel. Nevertheless, sociodemographic variables do not appear to have any explanatory power for consumers' intentions towards sustainable hotels; the only one that shows any influence is gender.

In this vein, our results confirm recent developments of the theory of planned behavior and information processing theory, in which different authors have proposed previous experiences and consumer's awareness and information as relevant factors that influence intentions (e.g., $[6,14,20,40,60])$. Adding to previous analyses of the hotel industry under this theory, our findings show that the formation of intentions depends on different factors and that awareness of hotels' sustainable practices-whether through knowledge based on hotels' certifications, on previous experiences, or specific searches for information about sustainable practices-plays a crucial role in this process. In line with other research (e.g., $[14,39])$, we conclude that awareness must be included in the model in studies that analyze 
consumers' intentions. The addition of new variables could improve the framework proposed in the theory of planned behavior [35].

We thus contribute to the understanding of the factors that influence consumers' intentions. Nova-Reyes et al. [1], in a recent review on the topic of socially responsible consumer behavior, state that the change to a more sustainable consumption model and to the promotion of responsible management and growth requires an understanding of consumers' behavior, and that this can be obtained through academic research on related trends. By providing more data about the factors that affect consumers' intentions regarding sustainability, we contribute to this aim.

Our study confirms and extends the results of Kang et al. [2], Han et al. [6] and Fuentes-Moraleda et al. [3], which specifically analyze the effect of different antecedents on consumers' WTPM for sustainable hotels. Each of those studies analyzes different customer concerns or attitudes, and we enrich this analysis by confirming that information, certifications and previous experiences also influence consumers' WTPM for sustainable hotels. If consumers do not know about the hotel's practices regarding sustainability, it is harder for them to assign a value to these actions.

Sociodemographic characteristics do not have strong explanatory power for WTPM for hotels with sustainable practices. In light of our results, only gender can be said to have some influence, but further analysis is required. There is no consensus in the literature about the direction and effect of these factors, although similar results are reported in the studies by Kang et al. [2] and Han et al. [6].

Therefore, the arguments related to cognitive processes and the different information processing abilities depending on age, to the resources related with education and income, or to the cultural distance between different nationalities, proposed in previous literature, could have an influence on other factors, such as the antecedents of the intentions analyzed here; however, although they merit further research, they do not have an effect on the WTPM for a sustainable hotel.

Therefore, managers in the hotel sector could derive important lessons from our results. First, given the importance of consumers being aware of CSR practices, we would recommend increasing communication about and facilitating access to the information about the hotel's CSR practices, since more informed consumers are more willing to pay a premium for sustainable hotels. Second, certification schemes also play an important role for consumers, since they provide external guarantees about the practices applied by hotels and could also be a source of information for stakeholders. Hotels should thus make information about certifications easily accessible to potential customers. Furthermore, efforts should be made to retain customers that have sustainability concerns, since customers with experience with sustainable hotels are more willing to pay extra for a hotel engaging in these practices. These efforts could yield higher returns than segmenting customers according to sociodemographic variables.

Enhancing consumers' intentions regarding sustainable practices could also reinforce hotels' voluntary adoption of practices that protect the environment and positively affect society, while also boosting their own competitiveness. In turn, this will generate positive effects for all actors in society.

This study has certain limitations that constitute avenues for further research. First, although the analysis allows us to study factors affecting WTPM for sustainable hotels, the lack of a causal analysis due to the cross-sectional nature of the sample can be improved in future studies by developing a panel data that would allow these effects to be tested. In addition, more recent periods should be included, in order to analyze the evolution in intentions and test whether there are any changes in the relationships proposed. Second, although we collected extensive data that included tourists from different countries, the survey was only administered to visitors in a single Spanish city. It would be interesting to compare these results with analyses of visitors to other areas or countries, or even to specific hotels, in order to compare customer intentions and behaviors in different hotel types and in hotels with different levels of CSR practices. Third, further research should also analyze whether sociodemographic variables have some explanatory power in other factors that affect intentions, for example, on the way consumers access the information to raise awareness of sustainability issues. Finally, including the number or frequency of previous experiences and distinguishing between the 
effects of different kinds of sustainability certificates, would allow us to refine the analysis of the relationships under study here. In order to further examine the elements of the theory of planned behavior, future research should include all of them in the same model to analyze their joint effects, while also seeking to determine how consumer intentions are ultimately reflected in their behavior towards firms.

Author Contributions: Conceptualization, M.B.-N. and J.A.P.-A.; Data curation, J.A.P.-A.; Formal analysis, M.B.-N.; Funding acquisition, J.A.P.-A.; Investigation, M.B.-N. and J.A.P.-A.; Methodology, M.B.-N.; Resources, J.A.P.-A.; Software, M.B.-N.; Supervision, M.B.-N.; Validation, M.B.-N. and J.A.P.-A.; Writing-original draft, M.B.-N.; Writing-review and editing, M.B.-N. All authors have read and agreed to the published version of the manuscript.

Funding: This research received no external funding.

Conflicts of Interest: The authors declare no conflict of interest.

\section{References}

1. Nova-Reyes, A.; Muñoz-Leiva, F.; Luque-Martínez, T. The tipping point in the status of socially responsible consumer behavior. Sustainability 2020, 12, 3141. [CrossRef]

2. Kang, K.H.; Stein, L.; Heo, C.Y.; Lee, S. Consumers' willingness to pay for green initiatives of the hotel industry. Int. J. Hosp. Manag. 2012, 31, 564-572. [CrossRef]

3. Fuentes-Moraleda, L.; Lafuente-Ibanez, C.; Munoz-Mazon, A.; Villace-Molinero, T. Willingness to Pay More to Stay at a Boutique Hotel with an Environmental Management System. A Preliminary Study in Spain. Sustainability 2019, 11, 5134. [CrossRef]

4. Guzzo, R.F.; Abbott, J.; Madera, J.M. A Micro-Level View of CSR: A Hospitality Management Systematic Literature Review. Cornell Hosp. Q. 2019, 21. [CrossRef]

5. Chou, C.-J.; Chen, P.-C. Preferences and Willingness to Pay for Green Hotel Attributes in Tourist Choice Behavior: The Case of Taiwan. J. Travel Tour. Mark. 2014, 31, 937-957. [CrossRef]

6. Han, H.; Hsu, L.-T.J.; Lee, J.-S.; Sheu, C. Are lodging customers ready to go green? An examination of attitudes, demographics, and eco-friendly intentions. Int. J. Hosp. Manag. 2011, 30, 345-355. [CrossRef]

7. Chung, K.C. Green marketing orientation: Achieving sustainable development in green hotel management. J. Hosp. Mark. Manag. 2019. [CrossRef]

8. Elkington, J. Cannibals with Forks: The Triple Bottom Line of 21st Century Business. Altern. J. 1999, $25,42$.

9. Boronat-Navarro, M.; Antonio Perez-Aranda, J. Consumers' perceived corporate social responsibility evaluation and support: The moderating role of consumer information. Tour. Econ. 2019, 25, 613-638. [CrossRef]

10. Yadav, R.; Pathak, G.S. Determinants of Consumers' Green Purchase Behavior in a Developing Nation: Applying and Extending the Theory of Planned Behavior. Ecol. Econ. 2017, 134, 114-122. [CrossRef]

11. Xu, X.; Gursoy, D. Influence of sustainable hospitality supply chain management on customers' attitudes and behaviors. Int. J. Hosp. Manag. 2015, 49, 105-116. [CrossRef]

12. Masau, P.; Prideaux, B. Sustainable tourism: A role for Kenya's hotel industry. Curr. Issues Tour. $2003,6,12$. [CrossRef]

13. Lee, J.S.; Hsu, L.T.; Han, H.; Kim, Y. Understanding how consumers view green hotels: How a hotel's green image can influence behavioural intentions. J. Sustain. Tour. 2010, 18, 901-914. [CrossRef]

14. Perez, A.; de los Salmones, M.D.G. Information and Knowledge as Antecedents of Consumer Attitudes and Intentions to Buy and Recommend Fair-Trade Products. J. Nonprofit Public Sector Mark. 2018, 30, 111-133. [CrossRef]

15. World Tourism Organization. Tourism and the Sustainable Development Goals—Good Practices in the Americas; UNWTO: Madrid, Spain, 2018.

16. National Statistics Instituty of Spain. Estadística de Movimientos Turísticos En Fronteras (FRONTUR); National Statistics Instituty of Spain: Madrid, Spain, 2017.

17. Ajzen, H.; Fishbein, M. Understanding Attitudes and Predicting Social Behavior; Prentice-Hall: Englewood Cliffs, NJ, USA, 1980.

18. Ajzen, I. The theory of planned behavior. Organ. Behav. Hum. Decis. Process. 1991, 50, 179-211. [CrossRef] 
19. Yarimoglu, E.; Gunay, T. The extended theory of planned behavior in Turkish customers' intentions to visit green hotels. Bus. Strategy Environ. 2020, 29, 1097-1108. [CrossRef]

20. Namkung, Y.; Jang, S. Are Consumers Willing to Pay more for Green Practices at Restaurants? J. Hosp. Tour. Res. 2017, 41, 329-356. [CrossRef]

21. Cameron, T.A.; James, M.D. Estimating willingness to pay from survey data-An alternative pre-test-market evaluation procedure. J. Mark. Res. 1987, 24, 389-395. [CrossRef]

22. Krishna, A. Effect of dealing patterns on consumer perceptions of deal frequency and willingness to pay. J. Mark. Res. 1991, 28, 441-451. [CrossRef]

23. Homburg, C.; Koschate, N.; Hoyer, W.D. Do satisfied customers really pay more? A study of the relationship between customer satisfaction and willingness to pay. J. Mark. 2005, 69, 84-96. [CrossRef]

24. Rao, A.R.; Bergen, M.E. Price premium variations as a consequence of buyers lack of information. J. Consumer Res. 1992, 19, 412-423. [CrossRef]

25. Balaji, M.S.; Jiang, Y.; Jha, S. Green hotel adoption: A personal choice or social pressure? Int. J. Contemp. Hosp. Manag. 2019, 31, 3287-3305. [CrossRef]

26. Martinez Garcia de Leaniz, P.; Herrero Crespo, A.; Gomez Lopez, R. Customer responses to environmentally certified hotels: The moderating effect of environmental consciousness on the formation of behavioral intentions. J. Sustain. Tour. 2018, 26, 1160-1177. [CrossRef]

27. Fishbein, M.; Ajzen, I. Belief, Attitude, Intention, and Behavior: An Introduction to Theory and Research; Addison-Wesley: Reading, MA, USA, 1975.

28. Manaktola, K.; Jauhari, V. Exploring consumer attitude and behaviour towards green practices in the lodging industry in India. Int. J. Contemp. Hosp. Manag. 2007, 19, 13. [CrossRef]

29. Millar, M.; Baloglu, S. Hotel Guests' Preferences for Green Guest Room Attributes. Cornell Hosp. Q. 2011, 52, 302-311. [CrossRef]

30. Tang, C.M.F.; Lam, D. The role of extraversion and agreeableness traits on Gen Y's attitudes and willingness to pay for green hotels. Int. J. Contemp. Hosp. Manag. 2017, 29, 607-623. [CrossRef]

31. Barber, N.A.; Deale, C. Tapping Mindfulness to Shape Hotel Guests' Sustainable Behavior. Cornell Hosp. Q. 2014, 55, 100-114. [CrossRef]

32. Han, H.; Kim, Y. An investigation of green hotel customers' decision formation: Developing an extended model of the theory of planned behavior. Int. J. Hosp. Manag. 2010, 29, 659-668. [CrossRef]

33. Shaw, D.; Shiu, E. Ethics in consumer choice: A multivariate modelling approach. Eur. J. Mark. 2003, 37, 14. [CrossRef]

34. Ozcaglar-Toulouse, N.; Shiu, E.; Shaw, D. In search of fair trade: Ethical consumer decision making in France. Int. J. Consumer Stud. 2006, 30, 12. [CrossRef]

35. Wang, J.; Wang, S.; Wang, Y.; Li, J.; Zhao, D. Extending the theory of planned behavior to understand consumers' intentions to visit green hotels in the Chinese context. Int. J. Contemp. Hosp. Manag. 2018, 30, 2810-2825. [CrossRef]

36. Schlegelmilch, B.; Bohlen, G.; Diamantopoulos, A. The link between green purchasing decisions and measures of environmental consciousness. Eur. J. Mark. 1996, 30, 20. [CrossRef]

37. Gleim, M.R.; Smith, J.S.; Andrews, D.; Cronin, J.J. Against the Green: A Multi-method Examination of the Barriers to Green Consumption. J. Retail. 2013, 89, 44-61. [CrossRef]

38. Martinez-Perales, S.; Ortiz-Marcos, I.; Juan Ruiz, J.; Javier Lazaro, F. Using Certification as a Tool to Develop Sustainability in Project Management. Sustainability 2018, 10, 1408. [CrossRef]

39. Bamberg, S.; Ajzen, I.; Schmidt, P. Choice of travel mode in the theory of planned behavior: The roles of past behavior, habit, and reasoned action. Basic Appl. Soc. Psychol. 2003, 25, 175-187. [CrossRef]

40. Lam, T.; Hsu, C.H.C. Predicting behavioral intention of choosing a travel destination. Tour. Manag. 2006, 27, 589-599. [CrossRef]

41. Oh, H.; Hsu, C.H.C. Volitional degrees of gambling behaviors. Ann. Tour. Res. 2001, 28, 618-637. [CrossRef]

42. Perugini, M.; Bagozzi, R.P. The role of desires and anticipated emotions in goal-directed behaviours: Broadening and deepening the theory of planned behaviour. Br. J. Soc. Psychol. 2001, 40, 79-98. [CrossRef]

43. Bhatt, R.; Bhatt, K. Analyzing psychographic factors affecting green purchase intention. J. Contemp. Res. Manag. 2015, 10, 45 . 
44. Bang, H.K.; Ellinger, A.E.; Hadjimarcou, J.; Traichal, P.A. Consumer concern, knowledge, belief, and attitude toward renewable energy: An application of the reasoned action theory. Psychol. Mark. 2000, 17, 449-468. [CrossRef]

45. Tian, Z.; Wang, R.; Yang, W. Consumer Responses to Corporate Social Responsibility (CSR) in China. J. Bus. Ethics 2011, 101, 197-212. [CrossRef]

46. Bhattacharya, C.B.; Sen, S. Doing better at dong good: When, why, and how consumers respond to corporate social initiatives. Calif. Manag. Rev. 2004, 47, 9. [CrossRef]

47. Pomering, A.; Dolnicar, S. Assessing the Prerequisite of Successful CSR Implementation: Are Consumers Aware of CSR Initiatives? J. Bus. Ethics 2009, 85, 285-301. [CrossRef]

48. Miller, G.A. The magical number 7, plus or minus 2-Some limits on our capacity for processing information. Psychol. Rev. 1956, 63, 81-97. [CrossRef]

49. Sen, S.; Bhattacharya, C.B.; Korschun, D. The role of corporate social responsibility in strengthening multiple stakeholder relationships: A field experiment. J. Acad. Mark. Sci. 2006, 34, 158-166. [CrossRef]

50. Darnall, N.; Sides, S. Assessing the performance of voluntary environmental programs: Does certification matter? Policy Stud. J. 2008, 36, 95-117. [CrossRef]

51. Font, X. Environmental certification in tourism and hospitality: Progress, process and prospects. Tour. Manag. 2002, 23, 197-205. [CrossRef]

52. Geerts, W. Environmental certification schemes: Hotel managers' views and perceptions. Int. J. Hosp. Manag. 2014, 39, 87-96. [CrossRef]

53. Esparon, M.; Gyuris, E.; Stoeckl, N. Does ECO certification deliver benefits? An empirical investigation of visitors' perceptions of the importance of ECO certification's attributes and of operators' performance. J. Sustain. Tour. 2014, 22, 148-169. [CrossRef]

54. Chen, M.-F.; Tung, P.-J. The Moderating Effect of Perceived Lack of Facilities on Consumers' Recycling Intentions. Environ. Behav. 2010, 42, 824-844. [CrossRef]

55. Beck, L.; Ajzen, I. Predicting dishonest actions using the theory of planned behavior. J. Res. Personal. 1991, 25, 285-301. [CrossRef]

56. Bagozzi, R.P.; Kimmel, S.K. A comparison of leading theories for the prediction of goal-directed behaviours. Br. J. Soc. Psychol. 1995, 34, 437-461. [CrossRef]

57. Leone, L.; Perugini, M.; Ercolani, A. A comparison of three models of attitude-behavior relationships in the studying behavior domain. Eur. J. Soc. Psychol. 1999, 29, 28. [CrossRef]

58. Norman, P.; Conner, M. Predicting health-check attendance among prior attenders and nonattenders: The role of prior behavior in the theory of planned behavior. J. Appl. Soc. Psychol. 1996, 26, 1010-1026. [CrossRef]

59. Buhalis, D. Marketing the competitive destination of the future. Tour. Manag. 2000, 21, 97-116. [CrossRef]

60. Lee, M.J.; Back, K.-J. Association members' meeting participation behaviors: Development of meeting participation model. J. Travel Tour. Mark. 2007, 22, 18. [CrossRef]

61. Back, K.-J. The effects of image congruence on customers' brand loyalty in the upper middle-class hotel industry. J. Hosp. Tour. Res. 2005, 29, 19. [CrossRef]

62. Meyerslevy, J. The influence of a brand names association set size and word-frequency on brand memory. J. Consumer Res. 1989, 16, 197-207. [CrossRef]

63. Perez, A.; Rodriguez del Bosque, I. How customers construct corporate social responsibility images: Testing the moderating role of demographic characteristics. BRQ Bus. Res. Q. 2015, 18, 127-141. [CrossRef]

64. Dietz, T.; Kalof, L.; Stern, P.C. Gender, values, and environmentalism. Soc. Sci. Q. 2002, 83, $353-364$. [CrossRef]

65. Tajfel, H.; Turner, J. The social identity theory of intergroup behavior. In Psychology of Intergroup Relations; Worchel, S., Austin, L., Eds.; Nelson-Hall: Chicago, IL, USA, 1986; pp. 7-24.

66. Saad, G.; Gill, T. Applications of evolutionary psychology in marketing. Psychol. Mark. 2000, 17, 1005-1034. [CrossRef]

67. Blocker, T.J.; Eckberg, D.L. Gender and environmentalism: Results from the 1993 General Social Survey. Soc. Sci. Q. 1997, 78, 841-858.

68. Morris, M.G.; Venkatesh, V. Age differences in technology adoption decisions: Implications for a changing work force. Pers. Psychol. 2000, 53, 375-403. [CrossRef] 
69. Diamantopoulos, A.; Schlegelmilch, B.B.; Sinkovics, R.R.; Bohlen, G.M. Can socio-demographics still play a role in profiling green consumers? A review of the evidence and an empirical investigation. J. Bus. Res. 2003, 56, 465-480. [CrossRef]

70. Turley, L.; Cabaniss, R.F. Price knowledge for services: An empirical investigation. J. Prof. Serv. Mark. 1995, $12,13$.

71. Kuchinka, D.G.J.; Balazs, S.; Gavriletea, M.D.; Djokic, B.-B. Consumer Attitudes toward Sustainable Development and Risk to Brand Loyalty. Sustainability 2018, 10, 997. [CrossRef]

72. Peterson, M.F.; Smith, P.B. Social structures and processes in cross-cultural management. In The Handbook of Cross-Cultural Management Research; Smith, P.B., Peterson, M.F., Thomas, D.C., Eds.; Sage: Thousand Oaks, CA, USA, 2008; pp. 35-58.

73. Kang, M.; Moscardo, G. Exploring cross-cultural differences in attitudes towards responsible tourist behaviour: A comparison of Korean. Asia Pacific J. Tour. Res. 2006, 11, 17.

74. Cordano, M.; Welcomer, S.; Scherer, R.; Pradenas, L.; Parada, V. Understanding Cultural Differences in the Antecedents of Pro-Environmental Behavior: A Comparative Analysis of Business Students in the United States and Chile. J. Environ. Educ. 2010, 41, 224-238. [CrossRef]

75. Hudson, S.; Ritchie, J.B. Cross-cultural tourist behavior: An analysis of tourist attitudes towards the environment. J. Travel Tour. Mark. 2001, 10, 22. [CrossRef]

76. Maignan, I. Consumers' perceptions of corporate social responsibilities: A cross-cultural comparison. J. Bus. Ethics 2001, 30, 57-72. [CrossRef]

77. Takayama, N.; Petrova, E.; Matsushima, H.; Furuya, K.; Ueda, H.; Mironov, Y.; Petrova, A.; Aoki, Y. Values, Concerns, and Attitudes Toward the Environment in Japan and Russia. Urban Reg. Plan. Rev. 2015, 2, 25. [CrossRef]

78. Top 100 Destinations Ranking. 2015. Available online: https://blog.euromonitor.com/top-100-citydestinations-ranking/ (accessed on 20 April 2015).

79. Ajuntament de Barcelona. Informe de l'activitat Turística a Barcelona. Available online: https://www.bcn.cat/ estadistica/castella/dades/anuari/cap13/C1302010.htm (accessed on 1 April 2015).

80. Perez Tapia, G.; Mercade Mele, P.; Almeida-Garcia, F. Corporate image and destination image: The moderating effect of the motivations on the destination image of Spain in South Korea. Asia Pacific J. Tour. Res. 2019, 24, 70-82. [CrossRef]

81. Mercade Mele, P.; Molina Gomez, J.; Jose Sousa, M. Influence of Sustainability Practices and Green Image on the Re-Visit Intention of Small and Medium-Size Towns. Sustainability 2020, 12, 930. [CrossRef]

82. Li, Y.; Zhang, Z.; Wang, R.; Chen, Y. Consumer Purchase Intention toward Crowdfunding Products/Services: A Cost-Benefit Perspective. Sustainability 2019, 11, 3579. [CrossRef]

83. Forbes, S.L.; Cohen, D.A.; Cullen, R.; Wratten, S.D.; Fountain, J. Consumer attitudes regarding environmentally sustainable wine: An exploratory study of the New Zealand marketplace. J. Clean. Prod. 2009, 17, 1195-1199. [CrossRef]

84. Eustice, C.; McCole, D.; Rutty, M. The impact of different product messages on wine tourists' willingness to pay: A non-hypothetical experiment. Tour. Manag. 2019, 72, 242-248. [CrossRef]

85. Amatulli, C.; De Angelis, M.; Korschun, D.; Romani, S. Consumers' perceptions of luxury brands' CSR initiatives: An investigation of the role of status and conspicuous consumption. J. Clean. Prod. 2018, 194, 277-287. [CrossRef]

86. Ajuntament de Barcelona. Anuario Estadístico de la Ciudad de Barcelona. Available online: https: //www.bcn.cat/estadistica/castella/dades/anuari/cap13/C1306010.htm (accessed on 1 April 2015).

87. Podsakoff, P.M.; MacKenzie, S.B.; Lee, J.Y.; Podsakoff, N.P. Common method biases in behavioral research: A critical review of the literature and recommended remedies. J. Appl. Psychol. 2003, 88, 879-903. [CrossRef]

88. Pérez-Aranda, J.; Boronat-Navarro, M. Which corporate social responsibility issues do consumers perceive as relevant to be evaluated in the hotel sector? Eur. J. Int. Manag. 2020. accepted paper.

89. Szolnoki, G.; Hoffmann, D. Online, face-to-face and telephone surveys-Comparing different sampling methods in wine consumer research. Wine Econ. Policy 2013, 2, 57-66. [CrossRef]

90. Vitale, S.; Biondo, F.; Giosue, C.; Bono, G.; Okpala, C.O.R.; Piazza, I.; Sprovieri, M.; Pipitone, V. Consumers' Perception and Willingness to Pay for Eco-Labeled Seafood in Italian Hypermarkets. Sustainability 2020, 12, 1434. [CrossRef] 
91. Agresti, A.; Finlay, B. Statistical Methods for the Social Sciences; Prentice-Hall: Upper Saddle River, NJ, USA, 2009.

92. Cohen, J. Statistical power analysis for the behavioral sciences. Percept. Motor Skills 1988, 67, 1007.

93. Homburg, C.; Stierl, M.; Bornemann, T. Corporate Social Responsibility in Business-to-Business Markets: How Organizational Customers Account for Supplier Corporate Social Responsibility Engagement. J. Mark. 2013, 77, 54-72. [CrossRef]

94. Du, S.; Bhattacharya, C.B.; Sen, S. Maximizing Business Returns to Corporate Social Responsibility (CSR): The Role of CSR Communication. Int. J. Manag. Rev. 2010, 12, 8-19. [CrossRef]

95. Kim, D.-Y.; Wen, L.; Doh, K. Does cultural difference affect customer's response in a crowded restaurant environment? A comparison of American versus Chinese customers. J. Hosp. Tour. Res. 2010, 34, 103-123. [CrossRef]

(C) 2020 by the authors. Licensee MDPI, Basel, Switzerland. This article is an open access article distributed under the terms and conditions of the Creative Commons Attribution (CC BY) license (http://creativecommons.org/licenses/by/4.0/). 